https://doi.org/10.32689/2618-0065-2020-3(5)-34-47

Барзилович Анастасія Дмитрівна, кандидат медичних наук, директор, МЦ «КіндерКлінік», 03039, м. Київ, вул. Вишгородська, 45/2, тел.: 0632156835, e-mail: A.barzylovych@gmail.com, https//orcid.org/0000-00020330-5147.

\title{
ФІНАНСОВИЙ МЕХАНІЗМ ДЕРЖАВНОГО РЕГУЛЮВАННЯ РОЗВИТКУ ОХОРОНИ ЗДОРОВ'Я УКРАЇНИ
}

Анотація. Величезне значення такого блага, як здоров'я, зумовлює необхідність його постійної охорони. Забезпечення громадян лікувальнопрофілактичною допомогою на високому якісному рівні та в достатньому обсязі залежить від наявної матеріально-технічної бази медичних закладів, професіональної підготовки та кваліфікації спеціалістів медицини. Серед обов'язкових умов надання високоякісних медичних послуг $є$ фінансове забезпечення - один з фундаментальних чинників, що першочергово впливає на розвиток охорони здоров'я й соціально-економічну результативність медицини в цілому. Основною проблемою фінансування установ охорони здоров'я, надання медичних послуг для забезпечення галузі охорони здоров'я, є залишковий принцип, який пов'язаний із хронічним дефіцитом бюджетних коштів, виділених на вітчизняну медицину. У зв'язку із недостатнім фінансуванням та нераціональним використанням коштів державного бюджету, не в повному обсязі задоволення потреб населення в наданні медичних послуг, було прийнято рішення про реформування системи охорони здоров'я в Україні, що дасть змогу в короткі терміни мотивувати медичних працівників до надання якісної медичної допомоги населенню на всіх рівнях. У рамках спеціалізованої та стаціонарної медичної допомоги основним принципом вважається «гроші йдуть за пацієнтом». Установи охорони здоров'я у процесі проведення реформи $\epsilon$ тепер фінансово мотивованими на використання доказових (ефективних) методів лікування, щоб можна було позбутися недієвих (недоцільних) процедур. Створення автономності установ охорони здоров'я сприяє тому, що збільшується фінансова та господарська незалежність медичних установ, управління закладами стає більш гнучким, формуються стимули покращення надання якісних медичних послуг населенню, а також одночасно підвищується економічна ефективність використання лікарняних активів.

Ключові слова: фінансування, державний бюджет, охорона здоров'я, медичні послуги, лікування, бюджетні установи.

Barzylovych Anastasiia, $\mathrm{PhD}$ in Medical Sciences, Director, mc KinderKlinik, 03039, Kyiv, 45/2 Vishgorodska srt, tel.: 0632156835, e-mail: A.barzylovych@gmail.com, https//orcid.org/0000M0002M0330M5147. 


\title{
DYNAMICS OF FINANCING OF HEALTH CARE INSTITUTIONS IN UKRAINE
}

\author{
FINANCIAL MECHANISM OF STATE REGULATION OF \\ HEALTHCARE DEVELOPMENT OF UKRAINE
}

The great importance of such good as health, necessitates its constant protection. Providing citizens with treatment and preventive care at a high quality level and to a sufficient extent depends on the available material and technical facilities of medical institutions, professional training and qualification of medical specialists. Among the prerequisites for providing high quality health services is financial support - one of the fundamental factors that has a primary impact on health care development and the socio-economic performance of medicine as a whole. The main problem with financing health care institutions, the provision of health care services in the healthcare sector, is the residual principle, which is associated with the chronic shortage of budget allocations for domestic medicine. Due to insufficient funding and misuse of state budget funds, not fully meeting the needs of the population in the provision of health care services, a decision was made to reform the health care system in Ukraine, which will allow in a short time to motivate healthcare professionals to provide quality medical care to the population at all levels. Within the framework of specialized and inpatient medical care, the basic principle is "money follows the patient". Health care institutions in the process of reform are now financially motivated to use evidence-based (effective) treatments so that ineffective (inappropriate) procedures can be eliminated. Creating the autonomy of health care facilities contributes to increasing the financial and economic independence of health care facilities, managing facilities more flexibly, creating incentives to improve the provision of quality health care to the public, and at the same time increasing the economic efficiency of hospital assets.

Keywords: financing, state budget, health care, medical services, treatment, budgetary institutions.

Постановка проблеми. Що являє собою система охорони здоров'я? Дана система включає в себе організації, різноманітні інститути та сукупність ресурсів, за допомогою яких буде забезпечене надання населенню будь-якого пакенту медичних послуг з метою підтримання та відновлення здоров'я на належному рівні [1].

Україна, як і більшість країн світу, визнає охорону здоров'я одним із найбільш пріоритетних напрямів у діяльності держави та визначає, як соціальний, економічний та суспільний пріоритет. Зважаючи на те, що в контексті надання населенню якісних медичних послуг дана система потребує значних матеріальних та фінансових ресурсів.

Упродовж всього періоду існування незалежної України система охорони здоров'я являється однією із базових сфер діяльності, які регулюються на рівні держави. Державне регулювання системи охорони 
здоров'я, разом із питаннями менеджменту і ціноутворення, iï фінансування за рахунок коштів Державного бюджету, зумовило доволі повільне та недостатнє впровадження сучасних методів і способів менеджменту даною системою. Причина неналежного рівня фінансового механізму державного регулювання - в першу чергу нестача коштів, нераціональний їх розподіл, недосконалість наявних механізмів розподілу бюджетних коштів.

Перехід системи державного управління до ринкових відносин обумовлює збалансоване поєднання в системі фінансового регулювання надання населенню якісних медичних послуг надходження з різних джерел державного та спеціальних фондів. однак, на сьогодні важко визначити сумарний обсяг фінансових ресурсів для розвитку системи охорони здоров'я через відсутність достовірних даних або багатовекторність джерел фінансування.

Аналіз останніх дослдіжень і публікацій Доволі актуальним на сьогодні $\epsilon$ питання вдосконалення організації процесу фінансування та забезпечення установ охорони здоров'я України. Даний напрямок розглядається, як пріоритетний у зв’язку із обмеженими можливостями фінансувати установи виключно через державний бюджет. Авторами численних робіт економічного напрямку, таких як: Горин В.П. [2], Камінська Т.М. [3], Лопушняк Г.С. [4], Мальований М.I. [5], Москаленко В.Ф. [6], Смірнова Т.М. [7], Слабкий Г.О. та ін. [8], були висвітлені питання даної проблематики із наданням пропозицій та шляхів вирішення цієї проблеми. Основний акцент - це реформування наявної та побудова нової стратегічно доцільної системи охорони здоров'я в державі, коригування принципів фінансування системи, створення оптимальних умов для розвитку здорової конкуренції на ринку медичних послуг, а також стимулювання розвитку приватної медичної практики.

Незважаючи на колосальні здобутки науковців, питання з визначення джерел фінансового забезпечення установ охорони здоров'я в цілому, включаючи обсяги надходжень за кожним із таких джерел залишається недостатньо вивченим і потребує більш глибокого дослідження та аналізу.

Мета статті. Метою дослідження $\epsilon$ аналіз джерел фінансування як засобу державного регулювання системи охорони здоров'я України, пошук векторів його вдосконалення та впровадження сучасних методів і способів забезпечення населення доступними та якісними медичними послугами.

Виклад основого матеріалу. Конституцією України закріплене право кожного із громадян України на охорону здоров'я, також в Конституції зазначено, що медична допомога, яка надається населенню в державних i комунальних закладах, є безкоштовною та фінансується із бюджету держави [9].

Із метою визначення обсягів фінансування з державного та місцевого бюджетів, рівня безкоштовності надання медичної допомоги авторами був проведений аналіз обсягів фінансування установ охорони здоров'я за період 2017-2019 років.

Здоров'я нації - пріоритет уряду. Безкоштовна медична допомога, гарантована Україною, надається закладами охорони здоров'я, а саме: 
закладами, які визначаються окремим переліком Кабінету Міністрів України та перебувають у загальнодержавній власності й підпорядковані Міністерству охорони здоров'я України; закладами, які перебувають на балансі комунальної власності та підпорядковані органам місцевої влади та місцевого самоврядування [10].

Зважаючи на те, що основне джерело утримання установ охорони здоров'я України як і системи охорони здоров'я в цілому - це фінансування 3 Державного бюджету України, слід проаналізувати видатки на охорону здоров'я у структурі видатків Зведеного бюджету України за період 20162019 pp. [11].

Законом про Державний бюджет-2017, було змінено порядок надання 3 держбюджету місцевим бюджетам медичних субвенцій, а також було змінено формулу розподілу такої субвенції поміж місцевих бюджетів.

У 2017 році медична субвенція була спрямована на витрати місцевих бюджетів з метою оплати поточних витрат серед установ охорони здоров'я. Проте, серед видатків відсутні витрати на оплату енергопостачання та комунальних платежів - для цього у бюджеті було передбачено додаткову дотацію. Водночас слід зауважити, що кошти медичних субвенцій заборонено спрямовувати на капітальні витрати установ медицини або 3 метою здійснення заходів з оптимізації мережі медичних установ.

Згідно Постанови Кабінету Міністрів України № 242 від 20.0.2019 відбулися зміни у формулі розподілу обсягу медичних субвенції місцевим бюджетам з Державного бюджету України.

Водночас заборонене зменшення обсягу цільових коштів при плануванні, формуванні і подальшому затвердженні місцевих бюджетів.

Урядом врегульовано передачу коштів медичних субвенцій в межах ОТГ. Зокрема, 31 січня 2017 року радами ОТГ до місцевих бюджетів передаються кошти медичних субвенцій з метою забезпечення витрат для надання вторинної медичної допомоги у такому співвідношенні: не менше $60 \%$ від сукупного обсягу медичної субвенції, яка передбачається для ОТГ на базі районів; не менше $70 \%$ від сукупного обсягу медичної субвенції, що передбачається для ОТГ на основі міст обласного значення. Залишок від сукупного значення медичної субвенції (30-40\%) спрямовується на забезпечення надання первинної меддопомоги.

Основною відмінністю бюджету 2018 року для закладів охорони здоров'я стало те, що значний відсоток видатків було передбачено на сфери, де проводяться реформи.

Витрати Держбюджету у 2018 році у медичній сфері складали 86 млрд грн, тобто 9,1\% від сукупного бюджету та 2,6\% від ВВП. Бюджет був зорієнтований на забезпечення реформ у медицині, зокрема медичні працівники «первинки» перейшли на кардинально іншу систему оплати - державою передбачена компенсація за кожного пацієнта. 3 метою забезпечення тарифів-компенсацій витрати Держбюджету на первину медицину зросли на 36,9\%, що становило 13,28 млрд. грн. 
Було розширено урядову програму «Доступні ліки», яка охопила покриття більшого асортименту ліків за більш широким переліком медичних станів. Бюджет цієї програми у порівнянні з 2017 роком виріс на 42,9\% та становив 1 млрд грн.

На розвиток послуг із трансплантації на території України Урядом було виділено 112 млн. грн. даний стартап дозволить хворим на первинну легеневу гіпертензію або хронічну ниркову недостатність отримати повноцінне лікування не за кордоном, а на теренах України. Бюджет 2018 року забезпечив створення фундаментального рівня реперфузії. На закупівлю ангіографічного обладнання було виділено 150 мільйонів гривень, що дає змогу суттєво у подальшому зменшити смертність через інфаркт міокарда чи інсульт серед населення.

Для розвитку сільської медицини було виділено з державних коштів 1 мільярд гривень, завдяки чому чверть населення України відтепер можуть розраховувати на якісне медичне обслуговування. 53,9 мільярда гривень було розподілено на забезпечення екстреної, вторинної, а також третинної медицини. 3 метою забезпечення лікування громадян України за кордоном було виділено з державного бюджету 389,9 мільйона гривень [12].

Зведений бюджет на охорону здоров'я населення Украӥни у 2019 роиі склав 95,8 мільярдів гривень, що становило на 10\% більше у порівнянні з 2018 роком. Додаткове фінансування медичної сфери було спрямовано на забезпечення необхідних змін у сфері охорони здоров'я в Україні, зокрема:

Реформа закладів первинної допомоги склала 15,3 мільярди гривень. Усі установи, які спеціалізуються на наданні первинної медддопомоги, отримують кошти за надання медпослуг, тобто працює принцип «гроші йдуть за пацієнтом». До нової моделі фінансування вже залучено більше 60 відсотків медичних установ, які спеціалізуються на наданні первинної медичної допомоги.

На забезпечення функціонування програми «Безкоштовна діагностика» було виділено 2 мільярди гривень, за допомогою яких вдалося забезпечити покриття 80\% потреб пацієнта 3 діагностики у сімейних лікарів (рентген, УЗД, ЕКГ серця), а також лабораторні дослідження біологічного матеріалу і консультації спеціалістів вузького профілю. Даний перелік послуг безкоштовно пацієнтам надається виключно за скеруванням його сімейного лікаря.

Для забезпечення фінансування спеціалізованої амбулаторної, стаціонарної, а також екстреної меддопомоги місцевим бюджетам було надано субвенцій на 55,5 мільярдів гривень.

Слід зазначити, за кошти державного бюджету пілотний проект 3 розвитку екстреної медичної допомоги вдалося запустити у таких областях держави, як Вінницька, Донецька, Одеська, Полтавська, Тернопільська, а також у столиці. Комплексна програма у 922,5 мільйонів гривень увібрала в себе: покриття на 70\% потреби у спеціалізованому санітарного автомобільного транспорту для екстреної меддопомоги; підготовку (інструктаж) спеціалістів 3 метою підвищення їх кваліфікації на рівні 
світових стандартів здійснення екстреної медицини; витрати цільових коштів, розраховані на підвищення рівня оплати спеціалістів після проходження ними курсів 3 підвищення кваліфікації; манекени та спеціальне обладнання 3 метою забезпечення якісного проведення навчальносимуляційних тренінгів; єдині регіональні оперативно-диспетчерські групи; уніфіковані галузеві стандарти сучасної диспетчеризації.

Забезпечення закупівлі виробів медичного призначення та медикаментів склало суму 5,9 мільярдів гривень. Даною програмою забезпечено закупівлю ліків від важких захворювань, лікування яких $\epsilon$ тривалим та дороговартісним (дитяча та доросла онкологія, туберкульоз, гепатити, СНІД тощо); рідкісних хвороб (бульозний епідермоліз, легенева артеріальна гіпертензія, ювенільний ревматоїдний артрит, хвороба Віллебранда, імунодефіцити тощо). Сукупно ця програма покриває закупівлю за державні кошти більше 7 сотень медичних виробів та 50 лікарських препаратів [13].

У новій моделі фінансування закладів охорони здоров'я передбачається, що адміністративний механізм програми «Доступні ліки» стане централізованим та автоматизованим. Таким чином, за допомогою електронного рецепту, впровадженого в установах охорони здоров’я України, «доступні ліки» відпускають за номером рецепту на лікарські препарат - на мобільний телефон пацієнта надходить смс-повідомлення, що значно полегшує комунікацію лікаряпацієнта-провізора. У 2019 році даній програмі було виділено 1 мільярд гривень. Також, за кошти держави в сумі 925 мільйонів гривень була в повній мірі відшкодована вартість інсуліновмісних препаратів для пацієнтів, які страждають на діабет.

Установи охорони здоров'я отримали 150 мільйонів на розбудову мережі кардіологічних центрів, що дало змогу придбати 13 ангіографів у 2019 та 26 - у 2017-2018 роках. Таким чином, своєчасна діагностика коронарних захворювань за останніх 5 років дала змогу зменшити рівень смертності з причини гострого інфаркту міокарда на 20 \% [14].

Динаміка збільшення видатків у зведеному бюджеті на охорону здоров’я (табл. 1-4) представлена наступним чином:

Таблиця 1

Видатки зведеного бюджету на охорону здоров'я

\begin{tabular}{|c|c|}
\hline Рік & Кількість виділених коштів (млн. грн.) \\
\hline 2017 & $\mathbf{1 0 2 ~ 3 9 2 , 4 2 9}$ \\
\hline 2018 & $\mathbf{1 1 5 8 4 7 , 8 0 8}$ \\
\hline 2019 & $\mathbf{1 2 8 ~ 3 7 7 , 8 3 9}$ \\
\hline
\end{tabular}

Джерело: опрацьовано та сформовано автором на основі даних з Державної казначейської служби України [15]

Сумарно видатки на охорону здоров'я за 2017-2019 роки становили 346618,076 мільйонів гривень. У порівнянні з 2017 роком сума видатків у 
2018 році була вищою на 13455,379 млн. грн. (13,14\%) та на 25985,41 млн. грн. $(25,38 \%)$ у 2019 році відповідно.

Збільшення видатків на медицину в Україні упродовж останніх трьох років на чверть вказує на позитивну динаміку обраного фінансового методу державного регулювання надання населенню медичних послуг в Україні.

Таблиця 2

Видатки зведеного бюджету на заклади охорони здоров'я упродовж 2017-2019

рр. (грн.)

\begin{tabular}{|c|c|c|c|}
\hline П О КА З Н ИК И & 2017 рік & 2018 рік & 2019 рік \\
\hline Охорона здоров'я & $\begin{array}{l}102392429 \\
376,26\end{array}$ & $\begin{array}{l}115847808 \\
346,26\end{array}$ & $\begin{array}{l}128377839 \\
164,89\end{array}$ \\
\hline $\begin{array}{r}\text { Поліклініки і } \\
\text { амбулаторії, швидка та } \\
\text { невідкладна допомога }\end{array}$ & $\begin{array}{l}22783185 \\
666,98\end{array}$ & $\begin{array}{l}22481990 \\
448,67\end{array}$ & $\begin{array}{l}15906416 \\
211,61\end{array}$ \\
\hline $\begin{array}{l}\text { Поліклініки загального } \\
\text { профілю та амбулаторії }\end{array}$ & $\begin{array}{l}3704760 \\
972,69\end{array}$ & $\begin{array}{l}3140903 \\
213,50\end{array}$ & $\begin{array}{l}2125519 \\
262,32\end{array}$ \\
\hline $\begin{array}{c}\text { Спеціалізовані та } \\
\text { стоматологічні поліклініки }\end{array}$ & $\begin{array}{l}3432237 \\
905,14\end{array}$ & $\begin{array}{l}3544064 \\
707,65\end{array}$ & $\begin{array}{l}3819047 \\
769,58\end{array}$ \\
\hline $\begin{array}{l}\text { Станиї швидкої та } \\
\text { невідкладної допомоги }\end{array}$ & $\begin{array}{l}4758728 \\
751,37\end{array}$ & $\begin{array}{l}5894382 \\
545,87\end{array}$ & $\begin{array}{l}7608661 \\
045,89\end{array}$ \\
\hline $\begin{array}{r}\text { Фельдшерсько- } \\
\text { акушерські пункти }\end{array}$ & $\begin{array}{l}246807 \\
113,55\end{array}$ & $\begin{array}{l}216613 \\
072,18\end{array}$ & $\begin{array}{l}24343 \\
115,18\end{array}$ \\
\hline $\begin{array}{c}\text { Центри первинної } \\
\text { медичної (медико- } \\
\text { санітарної) допомоги }\end{array}$ & $\begin{array}{l}10640650 \\
924,23\end{array}$ & $\begin{array}{l}9686026 \\
909,47\end{array}$ & $\begin{array}{l}2328845 \\
018,64\end{array}$ \\
\hline $\begin{array}{l}\text { Лікарні та санаторно- } \\
\text { курортні заклади }\end{array}$ & $\begin{array}{l}62537740 \\
358,98\end{array}$ & $\begin{array}{l}68275421 \\
411,86\end{array}$ & $\begin{array}{l}72215909 \\
539,08\end{array}$ \\
\hline $\begin{array}{l}\text { Лікарні загального } \\
\text { профілю }\end{array}$ & $\begin{array}{l}41419535 \\
648,09\end{array}$ & $\begin{array}{l}44141356 \\
072,90\end{array}$ & $\begin{array}{l}46230056 \\
597,24\end{array}$ \\
\hline $\begin{array}{c}\text { Спеціалізовані лікарні } \\
\text { та інші спеціалізовані } \\
\text { заклади }\end{array}$ & $\begin{array}{l}16953760 \\
343,71\end{array}$ & $\begin{array}{l}19292696 \\
280,36\end{array}$ & $\begin{array}{l}21036701 \\
487,87\end{array}$ \\
\hline Пологові будинки & $\begin{array}{l}2382892 \\
322,86\end{array}$ & $\begin{array}{l}2700184 \\
733,07\end{array}$ & $\begin{array}{l}3027826 \\
255,46\end{array}$ \\
\hline $\begin{array}{l}\text { Санаторно-курортні } \\
\text { заклади }\end{array}$ & $\begin{array}{l}1781552 \\
044,32\end{array}$ & $\begin{aligned} 2141184 \\
325,53\end{aligned}$ & $\begin{array}{l}1921325 \\
198,51\end{array}$ \\
\hline $\begin{array}{c}\text { Санітарно- } \\
\text { профілактичні та } \\
\text { протиепідемічні заходи і } \\
\text { заклади }\end{array}$ & $\begin{array}{l}1469966 \\
015,63\end{array}$ & $\begin{array}{l}1646571 \\
910,06\end{array}$ & $\begin{array}{l}1881184 \\
338,53\end{array}$ \\
\hline $\begin{array}{l}\text { Фундаментальні та } \\
\text { прикладні дослідження і } \\
\text { розробки у сфері охорони } \\
\text { здоров'я }\end{array}$ & $\begin{array}{l}389887 \\
047,59\end{array}$ & $\begin{array}{r}482111 \\
437,88\end{array}$ & $\begin{array}{l}514526 \\
632,27\end{array}$ \\
\hline $\begin{array}{l}\text { Інша діяльність у } \\
\text { сфері охорони здоров'я }\end{array}$ & $\begin{array}{l}15211650 \\
287,08\end{array}$ & $\begin{array}{l}22961713 \\
137,79\end{array}$ & $\begin{array}{l}37859802 \\
443,40\end{array}$ \\
\hline Будинки дитини & $\begin{array}{l}689206 \\
354,26\end{array}$ & $\begin{array}{l}796538 \\
893,95\end{array}$ & $\begin{array}{l}874032 \\
128,03\end{array}$ \\
\hline
\end{tabular}




\begin{tabular}{|c|c|c|c|}
\hline П О К А З Н И К И & $\mathbf{2 0 1 7}$ рік & $\mathbf{2 0 1 8}$ рік & $\mathbf{2 0 1 9}$ рік \\
\hline Станції переливання & 483461 & 567577 & 609245 \\
крові & 803,33 & 835,79 & 518,74 \\
\hline $\begin{array}{c}\text { Інші заклади та } \\
\text { заходи усрері охорони }\end{array}$ & 14038982 & 21597596 & 36376524 \\
здоров'я & 129,49 & 408,05 & 796,63 \\
\hline
\end{tabular}

Джерело: опрацьовано та сформовано автором на основі даних 3 Державної казначейської служби України [15]

Таблиця 3

Видатки по загальному фонду на охорону здоров'я упродовж 2017-2019 рр.

(грн.)

\begin{tabular}{|c|c|c|c|}
\hline \multirow{2}{*}{ 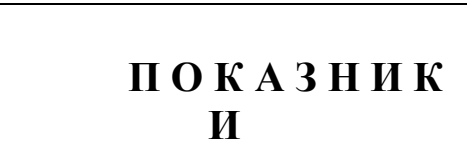 } & \multicolumn{3}{|c|}{ Загальний фонд } \\
\hline & 2017 рік & 2018 рік & 2019 рік \\
\hline $\begin{array}{l}\text { Охорона } \\
\text { Здоров'я }\end{array}$ & $\begin{array}{l}87889692 \\
366,36\end{array}$ & $\begin{array}{l}100072636 \\
560,19\end{array}$ & $\begin{array}{l}114388873 \\
334,12\end{array}$ \\
\hline $\begin{array}{r}\text { Поліклініки і } \\
\text { амбулаторії, швидка та } \\
\text { невідкладна допомога }\end{array}$ & $\begin{array}{l}20546742 \\
988,46\end{array}$ & $\begin{array}{l}20785824 \\
918,92\end{array}$ & $\begin{array}{l}13672330 \\
258,53\end{array}$ \\
\hline $\begin{array}{c}\text { Поліклініки } \\
\text { загального профілю та } \\
\text { амбулаторії }\end{array}$ & $\begin{array}{l}3289766 \\
489,09\end{array}$ & $\begin{array}{l}2877459 \\
988,93\end{array}$ & $\begin{array}{l}1957724 \\
944,43\end{array}$ \\
\hline $\begin{array}{c}\text { Спеціалізовані та } \\
\text { стоматологічні } \\
\text { поліклініки }\end{array}$ & $\begin{array}{l}2628719 \\
886,19\end{array}$ & $\begin{array}{l}2917580 \\
051,50\end{array}$ & $\begin{array}{l}3338980 \\
126,75\end{array}$ \\
\hline $\begin{array}{c}\text { Станиії швидкої } \\
\text { та невідкладної } \\
\text { допомоги }\end{array}$ & $\begin{array}{l}4651479 \\
603,22\end{array}$ & $\begin{array}{l}5702463 \\
745,62\end{array}$ & $\begin{array}{l}6447029 \\
511,85\end{array}$ \\
\hline $\begin{array}{l}\text { Фельдшерсько- } \\
\text { акушерські пункти }\end{array}$ & $\begin{array}{l}236902 \\
896,94\end{array}$ & $\begin{array}{l}207917 \\
197,57\end{array}$ & $\begin{array}{l}17456 \\
942,28\end{array}$ \\
\hline $\begin{array}{c}\text { Центри первинної } \\
\text { медичної (медико- } \\
\text { санітарної) допомоги }\end{array}$ & $\begin{array}{l}9739874 \\
113,02\end{array}$ & $\begin{array}{l}9080403 \\
935,30\end{array}$ & $\begin{array}{l}1911138 \\
733,22\end{array}$ \\
\hline $\begin{array}{c}\text { Лікарні та } \\
\text { санаторно-курортні } \\
\text { заклади }\end{array}$ & $\begin{array}{l}52589638 \\
220,33\end{array}$ & $\begin{array}{l}58536456 \\
838,50\end{array}$ & $\begin{array}{l}63644282 \\
472,46\end{array}$ \\
\hline $\begin{array}{c}\text { Лікарні } \\
\text { загального профілюо }\end{array}$ & $\begin{array}{l}34894624 \\
996,40\end{array}$ & $\begin{array}{l}37726897 \\
188,96\end{array}$ & $\begin{array}{l}40530536 \\
904,90\end{array}$ \\
\hline $\begin{array}{c}\text { Спеціалізовані } \\
\text { лікарні та інші } \\
\text { спеціалізовані заклади }\end{array}$ & $\begin{array}{l}14274026 \\
623,96\end{array}$ & $\begin{array}{l}16925166 \\
347,26\end{array}$ & $\begin{array}{l}18795602 \\
976,94\end{array}$ \\
\hline Пологові будинки & $\begin{array}{l}1990433 \\
801,31\end{array}$ & $\begin{array}{l}2269698 \\
544,97\end{array}$ & $\begin{array}{l}2539427 \\
577,00\end{array}$ \\
\hline $\begin{array}{l}\text { Санаторно- } \\
\text { курортні заклади }\end{array}$ & $\begin{array}{l}1430552 \\
798,66\end{array}$ & $\begin{array}{c}1614694 \\
757,31\end{array}$ & $\begin{array}{l}1778715 \\
013,62\end{array}$ \\
\hline $\begin{array}{c}\text { Санітарно- } \\
\text { профілактичні та } \\
\text { протиепідемічні заходи і }\end{array}$ & $\begin{array}{l}1188896 \\
479,89\end{array}$ & $\begin{array}{l}1343474 \\
658,58\end{array}$ & $\begin{array}{r}1437245 \\
986,60\end{array}$ \\
\hline
\end{tabular}




\begin{tabular}{|c|c|c|c|}
\hline П О К А З Н И К & \multicolumn{3}{|c|}{ Загальний фонд } \\
\hline заклади & & & \\
\hline Фундаментальні & & & 390214 \\
та прикладні & & 315852 & 440,86 \\
$\begin{array}{c}\text { дослідження і розробки у } \\
\text { сфері охорони здоров'я }\end{array}$ & 241330 & 127,63 & 35244800 \\
\hline Інша діяльність у & 13323083 & 19091028 & 175,67 \\
сфері охорони здоров'я & 861,71 & 016,56 & 823969 \\
\hline Будинки дитини & 644795 & 736589 & 905,33 \\
\hline Станиії & 345,39 & 247,18 & 518318 \\
переливання крові & 841,31 & 483632 & 375,06 \\
\hline Інші заклади та & & 485,09 & 33902511 \\
заходи у сфері охорони & 12287382 & 17870806 & 895,28 \\
здоров'я & 175,01 & 284,29 & \\
\hline
\end{tabular}

Джерело: опрацьовано та сформовано автором на основі даних з Державної казначейської служби України [15]

Таблиця 4

Видатки зведеного бюджету по спеціальному фонду на заклади охорони здоров'я упродовж 2017-2019 рр. (грн.)

\begin{tabular}{|c|c|c|c|}
\hline \multirow[b]{2}{*}{ П О КА З Н И К И } & \multicolumn{3}{|c|}{ Спеціальний фонд } \\
\hline & 2017 рік & 2018 рік & 2019 рік \\
\hline Охорона здоров'я & $\begin{array}{l}14502737 \\
009,90\end{array}$ & $\begin{array}{l}15775171 \\
786,07\end{array}$ & $\begin{array}{l}13988965 \\
830,77\end{array}$ \\
\hline $\begin{array}{r}\text { Поліклініки і } \\
\text { амбулаторії, швидка та } \\
\text { невідкладна допомога }\end{array}$ & $\begin{array}{l}2236442 \\
678,52\end{array}$ & $\begin{array}{l}1696165 \\
529,75\end{array}$ & $\begin{array}{l}2234085 \\
953,08\end{array}$ \\
\hline $\begin{array}{c}\text { Поліклініки } \\
\text { загального профілю та } \\
\text { амбулаторії }\end{array}$ & $\begin{array}{l}414994 \\
483,60\end{array}$ & $\begin{array}{l}263443 \\
224,57\end{array}$ & $\begin{array}{l}167794 \\
317,89\end{array}$ \\
\hline $\begin{array}{c}\text { Спеціалізовані та } \\
\text { стоматологічні поліклініки }\end{array}$ & $\begin{array}{l}803518 \\
018,95\end{array}$ & $\begin{array}{l}626484 \\
656,15\end{array}$ & $\begin{array}{l}480067 \\
642,83\end{array}$ \\
\hline $\begin{array}{l}\text { Станиї швидкої та } \\
\text { невідкладної допомоги }\end{array}$ & $\begin{array}{l}107249 \\
148,15\end{array}$ & $\begin{array}{l}191918 \\
800,25\end{array}$ & $\begin{array}{l}1161631 \\
534,04\end{array}$ \\
\hline $\begin{array}{r}\text { Фельдшерсько- } \\
\text { акушерські пункти }\end{array}$ & $\begin{array}{l}9904 \\
216,61\end{array}$ & $\begin{array}{l}8695 \\
874,61\end{array}$ & $\begin{array}{l}6886 \\
172,90\end{array}$ \\
\hline $\begin{array}{c}\text { Центри первинної } \\
\text { медичної (медико- } \\
\text { санітарної) допомоги }\end{array}$ & $\begin{array}{l}900776 \\
811,21\end{array}$ & $\begin{array}{l}605622 \\
974,17\end{array}$ & $\begin{array}{l}417706 \\
285,42\end{array}$ \\
\hline $\begin{array}{c}\text { Лікарні та } \\
\text { санаторно-курортні заклади }\end{array}$ & $\begin{array}{l}9948102 \\
138,65\end{array}$ & $\begin{array}{l}9738964 \\
573,36\end{array}$ & $\begin{array}{l}8571627 \\
066,62\end{array}$ \\
\hline $\begin{array}{l}\text { Лікарні загального } \\
\text { профілю }\end{array}$ & $\begin{array}{l}6524910 \\
651,69\end{array}$ & $\begin{array}{l}6414458 \\
883,94\end{array}$ & $\begin{array}{l}5699519 \\
692,34\end{array}$ \\
\hline $\begin{array}{r}\text { Спеціалізовані } \\
\text { лікарні та інші } \\
\text { спеціалізовані заклади }\end{array}$ & $\begin{array}{l}2679733 \\
719,75\end{array}$ & $\begin{array}{l}2367529 \\
933,10\end{array}$ & $\begin{array}{l}2241098 \\
510,93\end{array}$ \\
\hline Пологові будинки & $\begin{array}{l}392458 \\
521,55\end{array}$ & $\begin{array}{l}430486 \\
188,10\end{array}$ & $\begin{array}{l}488398 \\
678,46\end{array}$ \\
\hline
\end{tabular}




\begin{tabular}{|c|c|c|c|}
\hline П ОКА З Н ИКИ & \multicolumn{3}{|c|}{ Спеціальний фонд } \\
\hline $\begin{array}{l}\text { Санаторно- } \\
\text { курортні заклади }\end{array}$ & $\begin{array}{l}350999 \\
245,66 \\
\end{array}$ & $\begin{array}{l}526489 \\
568,22 \\
\end{array}$ & $\begin{array}{l}142610 \\
184,89\end{array}$ \\
\hline $\begin{array}{c}\text { Санітарно- } \\
\text { профілактичні та } \\
\text { протиепідемічні заходи і } \\
\text { заклади } \\
\end{array}$ & $\begin{array}{l}281069 \\
535,74\end{array}$ & $\begin{array}{l}303097 \\
251,48\end{array}$ & $\begin{array}{r}443938 \\
351,93\end{array}$ \\
\hline $\begin{array}{l}\text { Фундаментальні та } \\
\text { прикладні дослідження і } \\
\text { розробки у сфері охорони } \\
\text { здоров'я }\end{array}$ & $\begin{array}{l}148556 \\
231,62\end{array}$ & $\begin{array}{l}166259 \\
310,25\end{array}$ & $\begin{array}{l}124312 \\
191,41\end{array}$ \\
\hline $\begin{array}{r}\text { Інша діяльність у } \\
\text { сфері охорони здоров'я }\end{array}$ & $\begin{array}{l}1888566 \\
425,37\end{array}$ & $\begin{array}{l}3870685 \\
121,23\end{array}$ & $\begin{array}{l}2615002 \\
267,73\end{array}$ \\
\hline Будинки дитини & $\begin{array}{l}44410 \\
508,87 \\
\end{array}$ & $\begin{array}{l}59949 \\
646,77 \\
\end{array}$ & $\begin{array}{l}50062 \\
222,70 \\
\end{array}$ \\
\hline $\begin{array}{l}\text { Станиії переливання } \\
\text { крові }\end{array}$ & $\begin{array}{l}92555 \\
962,02 \\
\end{array}$ & $\begin{array}{l}83945 \\
350,70 \\
\end{array}$ & $\begin{array}{l}90927 \\
143,68 \\
\end{array}$ \\
\hline $\begin{array}{r}\text { Інші заклади та } \\
\text { заходи у сфері охорони } \\
\text { здоров'я } \\
\end{array}$ & $\begin{array}{l}1751599 \\
954,48\end{array}$ & $\begin{array}{r}3726790 \\
123,76 \\
\end{array}$ & $\begin{array}{l}2474012 \\
901,35 \\
\end{array}$ \\
\hline
\end{tabular}

Джерело: опрацьовано та сформовано автором на основі даних з Державної казначейської служби України [15]

Серед видатків з держбюджету на установи охорони здоров’я у 2020 році вирішено виділити 108 мільярдів гривень, що є більше у порівнянні 3 2019 роком на 9,8 мільярдів. 3 метою забезпечення проведення реформ закладено

14,6 мільярдів субвенцій та 72,1 мільярди гривень на закупівлю лікарських препаратів, гарантій для первинної, спеціалізованої та екстреної медицини [16].

Однак, єдиного фінансування 3 централізованого та місцевого бюджетів для забезпечення оптимального функціонування медицини в Україні недостатньо. Тому варто залучати кошти від коштів лікарняних кас, а також медичного страхування громадян, доброчинних внесків. На сьогодні неможливо визначити реальну частку витрат громадян України на медицину. Тому, чимало авторів вважають доцільним використовувати статистичні дані щодо обсягу домогосподарств та їх середніх витрат на охорону здоров'я [10].

Також слід дотримуватися положення Національної стратегії реформування системи охорони здоров’я в Україні на період 2015-2020 рр. В ній зазначено, збільшення державних витрат без проведення змін в інфраструктурі не зможе забезпечити вирішення нагальних проблем. Слід докладати зусилля для перерозподілу наявних коштів та підвищувати ефективності системи охорони здоров'я. Аби вийти у короткі строки 3 економічної кризи уряду України слід проводити комплекс жорстких заходів. Це дасть змогу вплинути на доступність медичної допомоги [17].

Зважаючи на те, що левова частка державного фінансування установ охорони здоров'я - це джерела загального оподаткування, першопочаткове об'єднання коштів відбуватиметься на центральному рівні. Для того, щоб 
підвищити ефективність у відповідності до принципів децентралізації, значний відсоток центрального бюджету буде передано до агентств 3 фінансування охорони здоров'я на регіональному рівні.

Отже, слід знайти баланс між консолідацією коштів на центральному рівні для забезпечення окремих державних програм та збільшенням особистої відповідальності на місцевому рівні. Закупівля пакету медичних послуг за кошти державного бюджету повинна відбуватися насамперед на регіональному рівні у визначеному регуляторному полі.

3 метою підвищення ефективності функціонування системи охорони здоров'я слід відмовитися від постатейного фінансування. У зв'язку з цим заплановано та ефективно проводиться впровадження механізмів оплати, які зможуть забезпечити стимули для медичного персоналу негайно реагувати на потреби пацієнтів, забезпечуючи кожного відповідною допомогою, при цьому буде досягнуто ефективну та економну витрату коштів. Оптимальним варіантом для оплати праці на первинному рівні прийнято вважати подушні платежі, які коригуються за послуги і продуктивність (тобто, подушна оплата, яка враховує віко-статеві коефіцієнти - це подушна змішана оплата, яка охоплює також плату за послуги та оплату за результат).

У рамках спеціалізованої та стаціонарної медичної допомоги основним принципом вважається «гроші йдуть за пацієнтом». Перший крок у реформуванні системи фінансування із набуттям чинності Закону України «Про внесення змін до деяких законодавчих актів України щодо удосконалення законодавства 3 питань діяльності закладів охорони здоров'я» стало запровадження глобального бюджету для всіх лікарень із подальшим їх плавним переходом до системи оплати пацієнтом за пролікований випадок. Значною перевагою введення глобального бюджету є в тому числі отримання достовірної основної інформації про видатки в медицині. Лікарні зможуть самостійно використовувати свої заощаджені кошти, перепрофільовуючи їх на інші цілі, а також буде змога перенести їх на наступний рік, залишаючи на рахунку установи. Запровадження системи оплати за кожен випадок ставить на собі стимулювання лікарні до підвищення рівня надання лікувальних послуг при лікуванні станів і хвороб, так як установа охорони здоров'я зможе отримати відшкодування при розрахунку за кожен пролікований випадок. Це дасть змогу унеможливити надавати пацієнтам непотрібні послуги чи заохотити їх знаходитися на тривалому стаціонарному лікуванні. Використовуючи такий інструмент як діагностично-споріднена група (ДСГ), в державі з'явилася можливість порівняти продуктивність діючих лікарень та удосконалити саму систему контролю якості. Отже, установи охорони здоров'я у процесі проведення реформи $\epsilon$ тепер фінансово мотивованими на використання доказових (ефективних) методів лікування, щоб можна було позбутися недієвих (недоцільних) процедур, що в кінцевому рахунку дасть змогу вирішити проблему лікарень 3 надмірною кількістю ліжкомісць та/або кількістю лікарняних відділень.

Фінансовий механізм державного управління, який використовує НСЗУ, найбільш оптимально підходить для моделі своєчасного реагування 
на ситуацію 3 пандеміями (зокрема, актуальний на сьогодні спалах коронавірусу) та економічною кризою. Така модель фінансового регулювання забезпечує прогнозованість, у тому числі ефективний розподіл коштів, гнучкі методи розразунку. Країни, в яких вже запроваджено модель фінансування медичних послуг за допомогою єдино визначеного стратегічного закупівельника, зокрема, Великобританія, Канада та Швеція, на сьогодні демонструють одні з кращих показників у відповіді на боротьбу 3 інфекційними захворюваннями [19].

Висновки і перспективи подальших досліджень. Зведений бюджет на охорону здоров'я населення України у 2019 рочуі склав 95,8 мільярдів гривень, щзо становило на 10\% більше у порівнянні з 2018 роком. Реформа закладів первинної допомоги склала 15,3 мільярди гривень. Усі установи, які спеціалізуються на наданні первинної медичної допомоги, отримують кошти за надання медпослуг, тобто працює принцип «гроші йдуть за пацієнтом». До нової моделі фінансування вже залучено більше 60 відсотків медичних установ, які спеціалізуються на наданні первинної медичної допомоги. На забезпечення функціонування програми «Безкоштовна діагностика» було виділено 2 мільярди гривень, за допомогою яких вдалося забезпечити покриття 80\% потреб пацієнта 3 діагностики у сімейних лікарів (рентген, УЗД, ЕКГ серця), а також лабораторні дослідження біологічного матеріалу i консультації спеціалістів вузького профілю. Для забезпечення фінансування спеціалізованої амбулаторної, стаціонарної, а також екстреної меддопомоги місцевим бюджетам було надано субвенцій на 55,5 мільярдів гривень. У новій моделі фінансування закладів охорони здоров'я передбачається, що адміністративний механізм програми «Доступні ліки» стане централізованим та автоматизованим: за допомогою електронного рецепту «доступні ліки» відпускають за номером рецепту на лікарські препарат - на мобільний телефон пацієнта надходить смс-повідомлення, що значно полегшує комунікацію лікаря-пацієнта-провізора. Слід удосконалити існуючі джерела фінансування охорони здоров'я із врахуванням положення Національної стратегї реформування системи охорони здоров'я в Україні на період 2015 2020 рр. Розвиток нових джерел фінансування закладів охорони здоров'я, а саме: надання установам охорони здоров’я господарської автономії, що дасть змогу значно розширити повноваження керівників та вирішувати питання щодо самофінансування установ за рахунок коштів спеціального фонду; впровадження державно-приватного партнерства у сфері охорони здоров’я, яке буде спрямоване на залучення приватних інвестицій у державний (комунальний) сектор охорони здоров'я; фінансовий механізм державного управління, який використовуе НСЗУ, найбільш якісно забезпечуе прогнозованість, а також ефективний розподіл коштів, гнучкість у методах оплати.

\section{Література:}

1. Закон України «Основи законодавства України про охорону здоров'я» від 19.11.1992 р. № 2801-ХИ (зі змінами) [Електронний ресурс]. - Режим доступу : 
http://zakon5.rada.gov. ua/laws/show/2801-12.

2. Горин В.П. Формування фінансових ресурсів охорони здоров'я в контексті виконання критеріїв економічної безпеки / В.П. Горин // Наукові записки. Серія «Економіка». - 2015. - № 23. - С. 216-221.

3. Камінська Т.М. Децентралізація як умова ефективного фінансування лікувальних закладів/ Т.М. Камінська// Вектори розвитку фінансового потенціалу суб'єктів господарювання: матеріали Всеукр. наук.-практ. конф. (Харків, 1-5 лютого 2014 р.). - Харків, 2014.- С. 235-239.

4. Лопушняк ГС. Фінансове забезпечення державної політики у сфері охорони здоров'я / Г.С. Лопушняк // Менеджер. Вісник Донецького державного університету управління. - 2011. - № 3(57). - С. 112-123.

5. Мальований М.І. Стан та проблеми державного фінансування охорони здоров'я в Україні / М.I. Мальований // Проблеми економіки. - 2013. - № 4. - С. 116-124.

6. Москаленко В.Ф. Принципи побудови оптимальної системи охорони здоров'я: український контекст : [монографія] / В.Ф. Москаленко. - К. : Книга плюс, 2008. $-320 \mathrm{c}$.

7. Смірнова Т.М. Формування державної політики з охорони здоров'я в Україні / Т.М. Смірнова, О.P Ситенко // Вісник соціальної гігієни та організації охорони здоров'я в Україні. - 2014. - № 2(60). - С. 5-9.

8. Слабкий Г.О. Деякі уроки реформи охорони здоров'я України / Г.О. Слабкий [та ін.] // Україна. Здоров'я нації. - 2014. - № 3. - С. 7-22.

9. Конституція України [Електронний ресурс]. - Режим доступу : http://zakon2.rada.gov.ua/laws/show/254к/96-вp.

10.Державна служба статистики України [Електронний ресурс]. - Режим доступу : http://ukrstat.org/uk.

11.Державна казначейська служба України /Розподіл видатків бюджету за кодами програмної класифікації видатків [Електронний ресурс]. - Режим доступу : http://www.treasury.gov.ua.

12.Бюджет економічного зростання у сфері охорони здоров'я / [Електронний pecypc]. - Режим доступу: https://budget2018.info/ohorona.html

13.Офіційний сайт Міністерства охорони здоров'я [Електронний ресурс]. - Режим доступу: http://moz.gov.ua/zakupivli-likiv

14.Офіційний сайт Міністерства фінансів України [Електронний ресурс]. - Режим доступу: https://mof.gov.ua/uk/the-reform-of-medicine.

15.Державна казначейська служба України /Звітність про виконання державного бюджету [Електронний ресурс]. - Режим доступу : https://www.treasury.gov.ua/ua/file-storage/vikonannya-derzhavnogo-byudzhetu.

16.Офіційний сайт Міністерства фінансів України [Електронний ресурс]. - Режим доступу:

https://mof.gov.ua/uk/news/kabinet_ministriv_rozglianuv_proiekt_biudzhetu2020_i_vnis_iogo_do_verkhovnoi_radi-1801

17.Національна стратегія реформування системи охорони здоров'я в Україні на період 2015-2020 років [Електронний ресурс]. - Режим доступу: http://www.apteka.ua/ artide/327094.

18.Офіційний сайт Департаменту охорони здоров'я Чернівецької обласної державної адміністрації [Електронний ресурс]. - Режим доступу: http://www.medcv.gov.ua/archives/11630.

19. Фінансування закладів охорони здоров'я у 2020 році [Електронний ресурс]. Режим доступу: https://narkosumy.lic.org.ua/statti/finansuvannya-zakladiv-ohoronyzdorov-ya-u-2020-rotsi/. 


\section{REFERENCES:}

1. Zakon Ukrayini «Osnovi zakonodavstva Ukrayini pro ohoronu zdorov'ya» (1992) [Law of Ukraine "Fundamentals of Legislation of Ukraine on Health Care"], available at: http://zakon5.rada.gov. ua/laws/show/2801-12.

2. Gorin V.P. (2015) Formuvannya finansovih resursiv ohoroni zdorov'ya $v$ konteksti vikonannya kriteriyiv ekonomichnoyi bezpeki. Naukovi zapiski. «Ekonomika» [Formation of health care financial resources in the context of fulfilling the criteria of economic security. Scientific notes. Economy series]. - vol. 23., pp. 216-221.

3. Kaminska T.M. (2014) Decentralizaciya yak umova efektivnogo finansuvannya likuvalnih zakladiv. Vektori rozvitku finansovogo potencialu sub'yektiv gospodaryuvannya: materiali Vseukr. nauk.-prakt. konf. [Decentralization as a Condition for Effective Financing of Medical Institutions. Vectors of development of financial potential of economic entities: materials All-Ukrainian. Research Practice Conf.]. - pp. 235-239.

4. Lopushnyak G.S. (2011) Finansove zabezpechennya derzhavnoyi politiki u sferi ohoroni zdorov'ya. Menedzher. Visnik Doneckogo derzhavnogo universitetu upravlinnya [Financial support of public health policy / GS. Lopushnyak // Manager. Bulletin of Donetsk State University of Management]. - vol. 3(57). - pp. 112-123.

5. Malovanij M.I. (2013) Stan ta problemi derzhavnogo finansuvannya ohoroni zdorov'ya $v$ Ukrayini. Problemi ekonomiki [State and Problems of Public Health Financing in Ukraine. Problems of Economics]. - vol. 4. - pp.. 116-124.

6. Moskalenko V.F. (2008) Principi pobudovi optimalnoyi sistemi ohoroni zdorov'ya: ukrayinskij kontekst, monografiya [Principles of building an optimal health care system: Ukrainian context] - Kyiv, Kniga plyus.

7. Smirnova T.M. (2014) Formuvannya derzhavnoyi politiki z ohoroni zdorov'ya v Ukrayini. Visnik socialnoyi gigiyeni ta organizaciyi ohoroni zdorov'ya $v$ Ukrayini [Formation of the state health policy in Ukraine. Bulletin of social hygiene and health care organization in Ukraine]. vol. № 2(60). - pp. 5-9.

8. Slabkij G.O. (2014) Deyaki uroki reformi ohoroni zdorov'ya Ukrayini, Zdorov'ya naciyi [Some lessons from the health care reform of Ukraine. Nation's health.]. vol. 3. - pp. 7-22.

9. Konstituciya Ukrayini [Constitution of Ukraine] - available at: http://zakon2.rada.gov.ua/laws/show/254k/96-vr.

10. Derzhavna sluzhba statistiki Ukrayini [State Statistics Service of Ukraine], available at: http://ukrstat.org/uk.

11. Derzhavna kaznachejska sluzhba Ukrayini. Rozpodil vidatkiv byudzhetu za kodami programnoyi klasifikaciyi vidatkiv [State Treasury Service of Ukraine / Budget Expenditure Allocation by Program Classification of Expenditure Codes], - available at: http://www.treasury.gov.ua.

12. Byudzhet ekonomichnogo zrostannya u sferi ohoroni zdorov'ya (2017) [Healthcare Growth Budget], - available at: https://budget2018.info/ohorona.html

13. Oficijnij sajt Ministerstva ohoroni zdorov'ya. Zakupivli likiv [Purchase of medicines. Official Website of the Ministry of Finance of Ukraine], available at: http://moz.gov.ua/zakupivlilikiv.

14. Oficijnij sajt Ministerstva finansiv Ukrayini. Reforma mediciny [Official Website of the Ministry of Finance of Ukraine. The reform of medicine], available at: https://mof.gov.ua/uk/the-reform-of-medicine.

15. Derzhavna kaznachejska sluzhba Ukrayini. Zvitnist pro vikonannya derzhavnogo byudzhetu [State Treasury Service of Ukraine. State Budget Execution Report]. available at: https://www.treasury.gov.ua/ua/file-storage/vikonannya-derzhavnogo-byudzhetu.

16. Oficijnij sajt Ministerstva finansiv Ukrayini. Kabinet ministriv rozglianuv proiekt biudzhetu2020 I vnis iogo do verkhovnoi radi [Official Website of the Ministry of Finance of Ukraine. The Cabinet of Ministers reviewed the draft Budget 2020 and submitted it to the Verkhovna 
Rada],

available

https://mof.gov.ua/uk/news/kabinet_ministriv_rozglianuv_proiekt_biudzhetu-

2020_i_vnis_iogo_do_verkhovnoi_radi-1801.

17. Nacionalna strategiya reformuvannya sistemi ohoroni zdorov'ya v Ukrayini na period 20152020 rokiv [National Strategy for Healthcare Reform in Ukraine for 2015-2020], available at: http://www.apteka.ua/ artide/327094.

18. Oficijnij sajt Departamentu ohoroni zdorov'ya Cherniveckoyi oblasnoyi derzhavnoyi administraciyi (2019). Yak finansuvatimut medzakladi, peretvoreni na komunalni nekomercijni pidpriyemstva [Official site of the Department of Health of Chernivtsi Regional State Administration. How will medical institutions transformed into communal non-profit enterprises?], available at: http://www.medcv.gov.ua/archives/11630.

19. Finansuvannia zakladiv okhorony zdorovia u 2020 rotsi [Financing of health care facilities in 2020]. - available at: https://narkosumy.lic.org.ua/statti/finansuvannya-zakladiv-ohoronyzdorov-ya-u-2020-rotsi/. 